\title{
CHARACTERISTICS OF GENOME OF BACILLUS VELEZENSIS ONU 553 STRAIN ISOLATED FROM THE BOTTOM SEDIMENTS OF THE BLACK SEA
}

\author{
M.D. Shtenikov', A.M. Ostapchuk ${ }^{1}$, N.Y. Vasylieva ${ }^{1}$, A.M. Luzhetskyy ${ }^{2}$, \\ C. Rückert ${ }^{2}$, J. Kalinowski', V.O. Ivanytsia ${ }^{1}$ \\ ${ }^{1}$ Odessa I.I. Mechnikov National University, \\ 2 Dvoryanska Str., Odessa, 65000, Ukraine \\ ${ }^{2}$ Helmholtz Institute for Pharmaceutical Research Saarland, \\ Campus E8 1, Saarbrücken, 66123, Germany \\ e-mail:shtenikovnik@gmail.com
}

\begin{abstract}
The search for producers of biologically active metabolites is shifting towards the study of strains from exotic biotopes. Aerobic spore-forming bacteria from the Black Sea bottom sediments are a good example of such microorganisms due to the simplicity of selective isolation, culture maintenance, and high biosynthetic activity. Aim. To analyze the genome structure of Bacillus sp. ONU 553 bacterial strain, isolated from bottom sediments of the Black Sea, for its reidentification and to find genes responsible for the synthesis of biologically active compounds. Methods. The obtained genomic DNA was sequenced using HiSeq 1500 equipment (Illumina). Genome assembly was performed with a Newbler 2.8 assembler, species identification with a TYGS server, for ANI calculation Ezbiocloud was used. Genome annotation was done using a PATRIC and NCBI PGAP servers, search for biosynthetic gene clusters of antibiotics and bacteriocins using antiSMASH and Bagel4 respectively. Search for pathogenicity determinant was conducted using IslandViewer, for antibiotic resistance ResFinder-3.2, prophage elements search with PHASTER. Results. Established that the size of the studied genome of Bacillus sp. ONU 553 is 3934563 $b p$, the mean GC content is $46.69 \% .3953$ open reading frames were revealed, 3252 of them, i.e. $82 \%$ are identified. Determinants of six antibiotics and two bacteriocins and also four prophage-like elements were found. Conclusions. The conducted studies and comparative analysis of Bacillus sp. ONU 553 strain genome, which was isolated from the Black Sea bottom sediments gives us reasons to reidentify it as Bacillus velezensis and make perspective it's further study as potential probiotic and source of new biologically active compounds.
\end{abstract}

Keywords: Bacillus velezensis, genome annotation, marine bacteria, bottom sediments, the Black Sea, bacteriocins, antimicrobial compounds.

Sequential exhausting of land biotopes as sources of microorganisms producing biologically active compounds force investigators to look at the water inhabiting microorganisms, for example, such as of the sea origin [1]. From this point of view, the most interesting ones are seawater with specific physicochemical conditions, as the Black sea. The main producers of new bioactive compounds among the prokaryotes of sea origin are representatives of phyla Firmicutes (generally from Bacillus genus and affiliated) and Actinobacteria. Bacillus genus members are known for their unique ecophysiology and a wide spectrum of secondary metabolites, which potential is not fully exploited yet [2]. Among members of this genus especially wide sets of the secondary metabolites are characteristic for group Bacillus subtilis subgroup Bacillus amyloliquefaciens, in particular, species Bacillus velezensis [3]. Representatives of this species, as a genus in general, traditionally are recognized as plant-associated soil inhabitants [4]. There is a little information about the isolation of such bacteria from sea biotopes, especially, from bottom sediments [5], and the question about the aboriginality of such isolates remains open. Over the past years for marine Bacillus strains was shown an ability to synthesize new compounds with high biological activity. Nonribosomal peptides, such as bacilitetrins [6], pumilacidins [7] and marihysins [8], macrolides (macrolactin W [1], 
which has antibacterial activity and no cytotoxic one), thiopeptide bacteriocins YM-266183 and YM-266184 [6] can be attributed to them.

In our previous work, a gram-positive bacterium Bacillus sp. ONU 553 was isolated from the depth of $183 \mathrm{~m}$ in point with coordinates $44^{\circ} 30.000^{\prime} \mathrm{N}$ $31^{\circ} 05.000^{\prime} \mathrm{E}$, which has an antagonistic activity to a range of opportunistic microorganisms and can synthesize a wide spectrum of extracellular hydrolytic enzymes [9]. According to fatty acid spectrum data, this isolate was identified as B. amyloliquefaciens [10]. A combination of antagonistic activity against opportunistic fungal pathogens and the ability to synthesize hydrolytic enzymes became a ground for clarification of its taxonomy and further and deeper investigation of its biosynthetic potential.

The goal of this work was to analyze the genome structure of bacterium Bacillus sp. ONU 553 , isolated from bottom sediments of the Black Sea, its re-identification and revealing of genes, which are responsible for the biosynthesis of biologically active compounds. For solving the last task a genome mining was chosen, which is an effective tool for a search of biosynthetic gene cluster individual genomes because it among other makes possible to reveal genetic clusters which do not express under laboratory conditions due to some reason [11].

\section{MATERIALS AND METHODS}

The bacterial strain. As an object of this work, we have used the strain ONU 553 isolated from the bottom sediments of a shelf zone of the Black Sea from the depth of $183 \mathrm{~m}$ and subsequently identified with the fatty acids spectrum as B. amyloliquefaciens. The strain is deposited in the Collection of the sea and useful microorganisms of Odessa I.I. Mechnikov National University and designated as B. velezensis ONU 553.

Genomic DNA extraction. DNA was isolated using a modified method [12]. $10 \mathrm{ml}$ of day culture of studied strains grown on the LB broth in $30^{\circ} \mathrm{C}$ on rotary $160 \mathrm{rpm}$ shaker was harvested by centrifugation with $5000 \mathrm{rpm}$ for $10 \mathrm{~min}$. Pellets were resuspended in $450 \mu 1$ of TES buffer (50 мM glucose; 25 мM Tris- $\mathrm{HCl} \mathrm{pH}-8.0 ; 10 \mathrm{MM}$ EDTA) with added lysozyme in concentration $2 \mathrm{~g} / \mathrm{ml}$. The suspension was shaken and then placed to the thermostat with $37^{\circ} \mathrm{C}$ for $30 \mathrm{~min}$, the mix was slowly stirred every $10 \mathrm{~min}$. For further lysis of bacterial biomass subsequently with the next stirring were added $50 \mu 1$ of $5 \mathrm{M} \mathrm{NaCl}$ and
$120 \mu 1$ and $10 \%$ SDS and $10 \mu 1$ of protease K with $20 \mu \mathrm{g} / \mu 1$ concentration. The obtained mix was placed to the thermostat for 2 hours for $55^{\circ} \mathrm{C}$, carefully mixed every $30 \mathrm{~min}$ and cooled to room temperature. On the next stage $240 \mu 15 \mathrm{M}$ potassium acetate was added and suspension was placed on ice for $10 \mathrm{~min}$; after that it was intensively stirred 1-2 times for total mixing of tube content. The mix was centrifuged in $15000 \mathrm{rpm}$ for $10 \mathrm{~min}$ and $4^{\circ} \mathrm{C}$ temperature, supernatant with genomic DNA was carefully poured off to the clean tube and after adding $600 \mu 1$ of isopropyl alcohol was carefully mixed until reaching homogenous condition. DNA was precipitated by centrifuging at $15000 \mathrm{rpm}$ for $10 \mathrm{~min}$ and temperature $4^{0} \mathrm{C}$, the supernatant was poured off and added $1 \mathrm{ml}$ of $70 \%$ ethanol, centrifuged at $15000 \mathrm{rpm}$ for $10 \mathrm{~min}$ with temperature $4^{0} \mathrm{C}$, the supernatant was poured off. The procedure was repeated twice. The tube with genomic DNA was centrifuged for $1 \mathrm{~min}$ with maximal rpm and the remnants of alcohol were removed. After removing of alcohol tube was left open for room temperature for 10-15 min. 50 $\mu l$ of deionized water was added and DNA was carefully resuspended. $20 \mu \mathrm{l}$ of previously activated RNase with $5 \mu \mathrm{g} / \mathrm{ml}$ concentration was added to resuspended sample for purification of isolated total cell DNA from RNA impurities; samples were incubated at $37^{\circ} \mathrm{C}$ for 3-4 hours, the mixture was slowly stirred every $30 \mathrm{~min}$. Quality control of purified DNA was done on NANOdrop equipment DS-11FX+ and with horizontal electrophoresis in $1.5 \%$ agarose gel with constant voltage $150 \mathrm{~V}$ for $40 \mathrm{~min}$. All used reagents were from Sigma, enzymes were from New England Biolabs.

DNA sequencing. DNA sequencing was conducted in Helmholtz Institute for Pharmaceutical Research Saarland. Sequencing was done using two libraries with short and long inserts on HiSeq 1500 equipment (Illumina).

Bioinformatic tools used. De novo assembly was done using the Newbler assembler (version 2.8). For species identification based on $16 \mathrm{~S}$ RNA gene sequence and whole-genome comparison TYGS tool was used [13]. OrthoANI calculation was done using Ezbiocloud [14]. Genome annotation was conducted using PATRIC [15] and NCBI PGPAP [16] servers, and comparative analysis - SEED, respectively [17].

Results of NCBI and PATRIC annotations were compared by BEACON [18]. According to the results of PATRIC annotation, a genome map was created using resources of the same server. 
Search for a biosynthetic cluster of bacteriocins and antibiotics was conducted with antiSMASH [19] and Bagel4 [20], respectively. Search for pathogenicity determinants was done using Island Viewer [21] and VirulenceFinder 2.0 [22], for antibiotic resistance determinants search we have used ResFinder [23], and for prophage elements PHASTER [24].

\section{RESULTS}

Identification of the studied strain Bacillus sp. ONU 553 using whole-genome comparison tool TYGS revealed that given genome belongs to $B$. velezensis species (B. subtilis group, $B$. amyloliquefaciens subgroup). Index of digital DNA-DNA hybridization of this genome with the genome of Bacillus velezensis FZB42 is equal to $95.8 \%$, which very much exceeds the cutoff value for species delineating (70\%). OrthoANI (average nucleotide identity) between strains $B$. velezensis ONU 553 and $B$. velezensis FZB42 is equal to 98.87, which is also higher than the corresponding cutoff value (which is $95 \%$ ). The same index for B. amyloliquefaciens DSM7/ B. velezensis ONU 553 pair is $94.28 \%$, which is also less than the cutoff of $95 \%$.

B. velezensis ONU 553 genome is represented by a circular chromosome, with a size of 3934563 $\mathrm{bp}$, that is about $16 \mathrm{~kb}$ more than in $B$. velezensis FZB42. GC content is $46.69 \%$, that in significantly exceeds the maximal known index for this species (46.64 \%) [2]. Comparative analysis of genomes has shown that the first insertion in the site 599372$645952 \mathrm{bp}$ is about $46 \mathrm{~kb}$ in size and contains some phage-specific proteins. These and PHASTER data, (see Table 3, line 1) prove that this site belongs to a prophage. The second insert, $27 \mathrm{~kb}$ in size with coordinates $3351458-3378255 \mathrm{bp}$, contains a polyketide synthase cluster. Localization of this cluster corresponds to the beginning of revealed there but not identified by the antiSMASH cluster (Table 2). The above-mentioned excess of genetic material is partly compensated by a large number of insertions in the genome of B. velezensis FZB42.

Using the PATRIC server in the genome of strain $B$. velezensis ONU 5533953 open reading frames were found, the biological function was identified for 3252 of them (82\%), and 701 remained hypothetical. Also, we have identified 113 RNA genes, among them, 86 tRNA, and 27 rRNA genes. A comparison of annotation results with NCBI PGAP and PATRIC is presented in Table 1. Regarding minor differences between them and a lack of a useful tool for genome annotation visualization, for results representation was chosen the in-built tool of the PATRIC (Fig. 1).

Search for bacteriocins using Bagel4 revealed genetic clusters, determining the biosynthesis of two compounds - LCI-like bacteriocin and amylocyclicin. These bacteriocins are known for the species $B$. velezensis. The first one, according to Bagel4 data, belongs to a comparatively poorly studied group of LCI-like bacteriocins. A prototypical protein of this group (LCI) is known for its activity against Xantomonas campestris pv. oryzae, an important pathogen of rice plants [25]. The second one belongs to the group of so-called head-to-tail cyclized bacteriocins and is typical for the subgroup B. amyloliquefaciens [26]. Search for biologically active secondary metabolites using the antiSMASH system revealed 12 clusters, and only for 4 of them any known homologs were not found.

Among reliably identified clusters (that means antiSMASH similarity index is $100 \%$ ) were found functional clusters of polyketides - macrolactin and difficidin, and bacillaene, which are usually classified as polyketide, but are synthesized by hybrid polyketide-polypeptide synthetase [6]

\section{Table 1}

\section{Comparison of genome annotations for strain ONU 553 done with NCBI PGAP}

and PATRIC tools

\begin{tabular}{|l|c|c|}
\hline Annotation Features & NCBI PGAP & PATRIC \\
\hline CDS & 3733 & 3953 \\
\hline rRNA & 27 & 27 \\
\hline tRNA & 86 & 86 \\
\hline ncRNA & 4 & 0 \\
\hline Frameshifts/Pseudogenes & 107 & 2 \\
\hline Total & 3850 & 4066 \\
\hline Orphan genes & $430(11.17 \%)$ & $703(17.29 \%)$, \\
\hline Functional genes & $3420(88.83 \%)$ & $3363(82.71 \%)$ \\
\hline
\end{tabular}




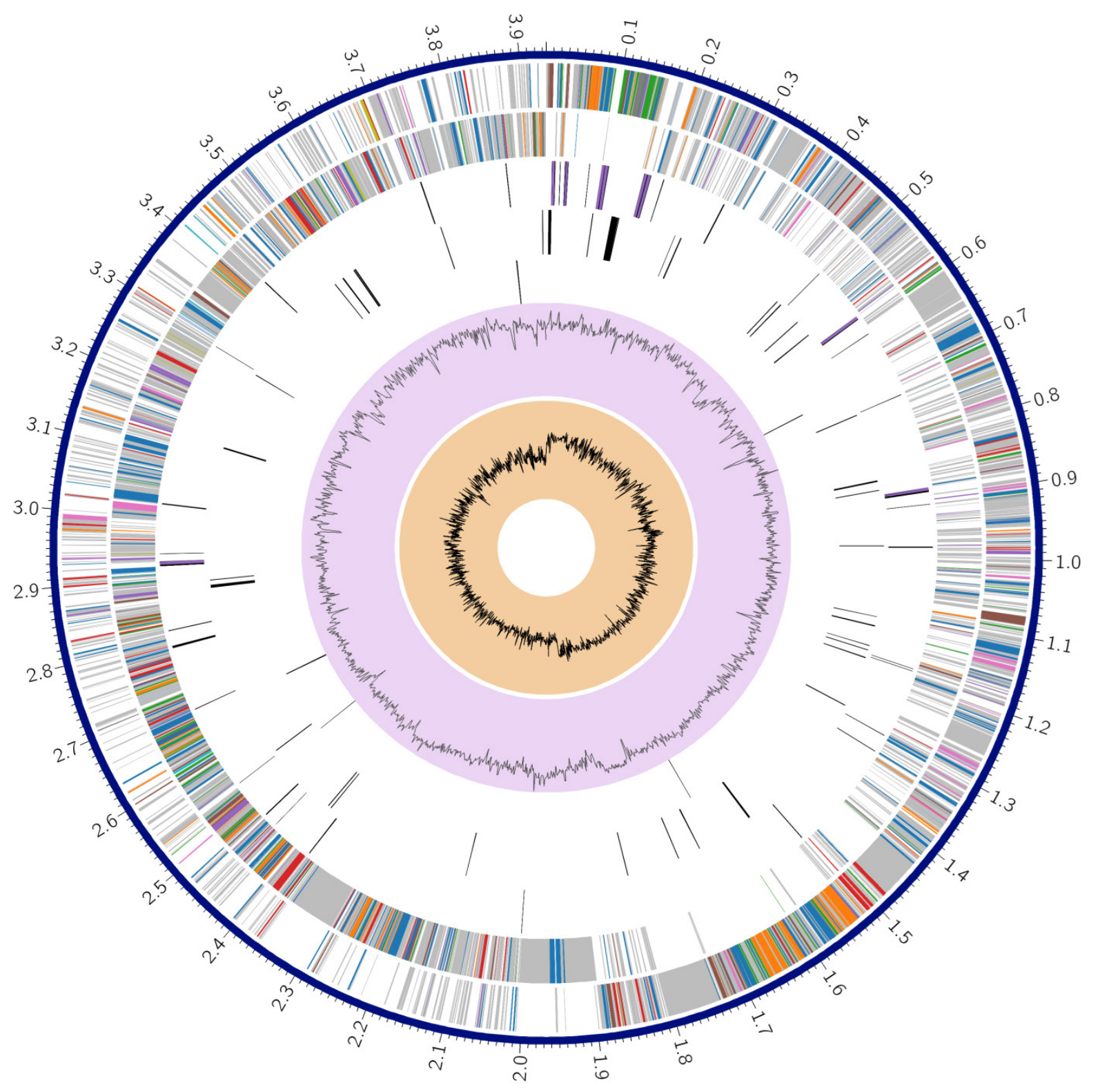

F i g. 1. Circular genome map of B. velezensis ONU 553. Legend: From outer to inner circles: contigs, open reading frames (ORF) on the leading strand, ORF on lagging strand, RNA genes, ORF with homology to known antimicrobial resistance genes, ORF with homology to known virulence factors, GC content, GC-skew. The colors of the ORF on the forward and reverse strands indicate the subsystem that these genes belong: blue - metabolism (722 ORF), green - protein processing (221), purple - stress response, defense, virulence (145), orange - cellular processes (242), red - bioenergetics (212), brown - DNA processing (80), pink - membrane transport (71), grey - RNA processing (52), yellow - cell envelope (16), light-blue - regulation and signal transfer (10), turquoise - miscellaneous (10).

(Table 2). These compounds are known for their bactericidal activity against human pathogens of the ESKAPE group (Enterococcus faecium, Staphylococcus aureus, Klebsiella pneumonia, Acinetobacter baumannii, Pseudomonas aeruginosa, Enterobacter spp.) and bacterial phytopathogens; macrolactins also possess an ability to inhibit proliferation of mouse melanoma cells and herpes simplex virus replication and HIV in lymphoblasts [6]. Because of their low stability, they did not reach yet even the clinical trials but can be a promising lead compound for drug design [11]. Unfortunately, on this stage of research is technically impossible to determine which variants of macrolactin and difficidin $B$. velezensis ONU 553 do synthesize. It can be solved in biochemical studies or by using bioinformatic tools more advanced than modern. 
Table 2

Characteristics and localization of clusters, found in the genome of B. velezensis ONU 553

\begin{tabular}{|c|c|c|c|c|c|}
\hline \multirow{2}{*}{ No } & \multirow{2}{*}{ Cluster } & \multicolumn{2}{|c|}{ Localisation, bp } & \multirow{2}{*}{$\begin{array}{l}\text { The most similar } \\
\text { known cluster }\end{array}$} & \multirow{2}{*}{ Similarity, $\%$} \\
\hline & & From & To & & \\
\hline 1 & Nonribosomal peptide synthetase & 311,938 & 376,796 & Syrfactin & 91 \\
\hline 2 & Polyketide synthase & 956,092 & 997,336 & Butyrosin & 7 \\
\hline 3 & Terpenoid synthesis enzymes & $1,084,807$ & $1,101,975$ & - & - \\
\hline 4 & Trans AT-polyketide synthase & $1,406,685$ & $1,494,504$ & Macrolactine & 100 \\
\hline 5 & $\begin{array}{l}\text { Combined nonribosomal peptide synthetase } \\
\text { /Trans AT-polyketidesynthase }\end{array}$ & $1,717,970$ & $1,827,173$ & Bacillaene & 100 \\
\hline 6 & Nonribosomal peptide synthetase & $1,884,833$ & $2,021,950$ & Fengycin & 100 \\
\hline 7 & Terpenoid synthesis enzymes & $2,044,982$ & $2,066,865$ & - & - \\
\hline 8 & Polyketidesynthase III type & $2,117,302$ & $2,158,402$ & - & - \\
\hline 9 & Trans AT-tranferase & $2,274,263$ & $2,380,436$ & Difficidin & 100 \\
\hline 10 & Bacteriocin & 299924 & 300217 & LCI & - \\
\hline 11 & Bacteriocin & 3052374 & 3049942 & Amylocyclicin & - \\
\hline 12 & Nonribosomal peptide synthetase & $3,003,787$ & $3,054,939$ & Bacillibactin & 100 \\
\hline 13 & Nonribosomal peptide synthetase & $3,337,057$ & $3,397,053$ & - & - \\
\hline 14 & Other & $3,599,120$ & $3,640,538$ & Bacilysin & 100 \\
\hline
\end{tabular}

\section{Table 3}

Prophage-like elements, found in the genome of $B$. velezensis ONU 553

\begin{tabular}{|l|c|c|c|c|c|}
\hline \multirow{2}{*}{ No } & \multirow{2}{*}{ Size $(\mathrm{kb})$} & \multirow{2}{*}{ Number of protein-coding ORFs } & \multicolumn{2}{|c|}{ Localization of prophage-like element } & \multirow{2}{*}{ GC content (\%) } \\
\cline { 4 - 5 } & & & From, bp & To, bp & \\
\hline 1 & 54.1 & 73 & 597321 & 651509 & 43.18 \\
\hline 2 & 9.9 & 15 & 1168469 & 1178415 & 45.75 \\
\hline 3 & 31.7 & 43 & 1229431 & 1261224 & 46.97 \\
\hline 4 & 24.8 & 10 & 1841385 & 1866281 & 41.21 \\
\hline
\end{tabular}

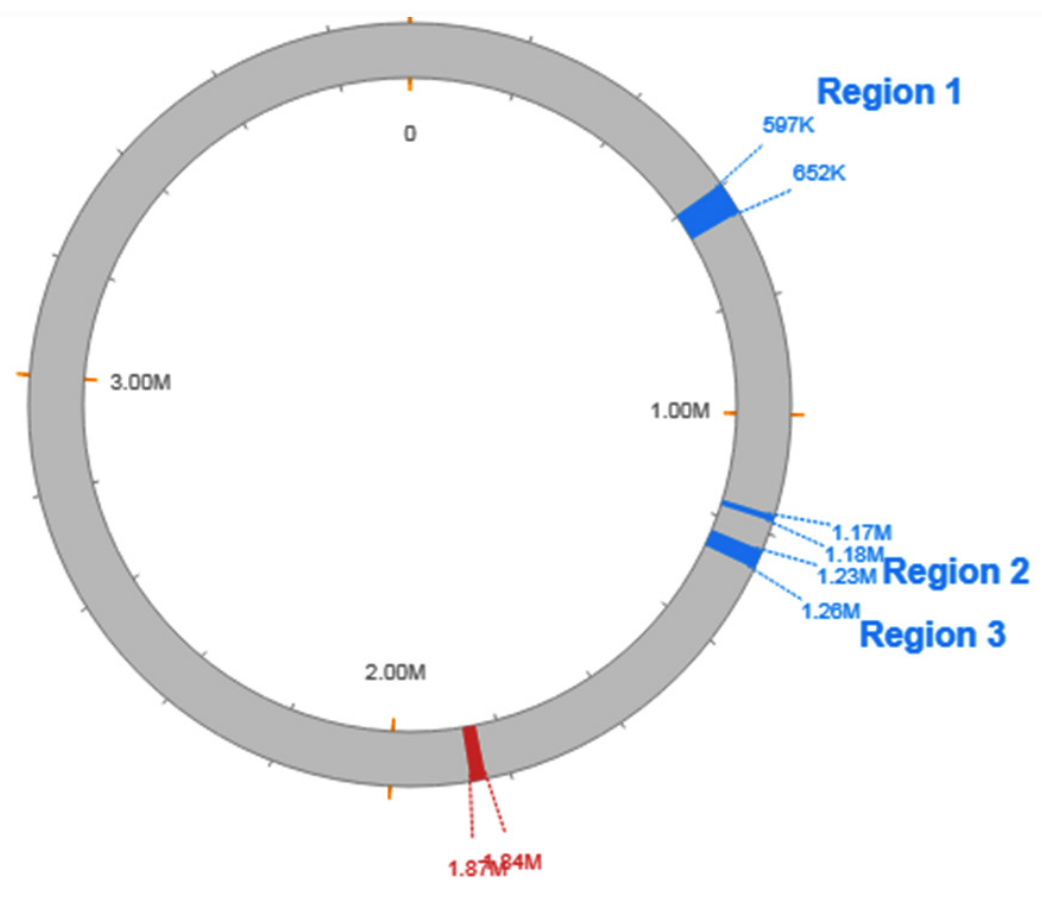

Region 4

F i g. 2. Circular genome map of studied strain B. velezensis ONU 553 with designated localization of prophage-like elements, found by PHASTER 
Clusters of nonribosomal lipopeptide fengycin, dipeptide bacilisyn, and siderophore bacillibactin were also found. Slightly less reliably is identified surfactin cluster ( $91 \%$ similarity) and with very poor one - cluster for aminoglycoside antibiotic butirosine ( $7 \%$ similarity) specific for bacilli.

Search using the IslandViewer and Virulence Finder 2.0 did not found any pathogenicity determinants. Conducted analysis using ResFinder did not found determinants of resistance to oxazolidinones, phosphomycin, nitroimidazoles, sulfanilamides, aminoglycosides, macrolides, glycopeptides, colistin, fusidic acid, chloramphenicol, quinolones, rifampin, trimethoprim, beta-lactams, and tetracycline. These data prove the safety of the potential use of this strain with biotechnological processes.

Out of four unidentified biosynthetic clusters, two belong to terpene biosynthesis enzyme complexes, one corresponds to an unknown nonribosomal peptide synthetase, another one - to unidentified polyketide synthase type III.

Search for prophage elements using PHASTER server has revealed four prophages. Localization, size and other parameters of these prophages are listed in Table 3. It is interesting to notice, that all revealed prophage-like elements are located in the same replichore (Fig. 2).

\section{DISCUSSION}

Conducted sequencing and analysis of the genome structure of studied strain have proved its preliminary identification based on the fatty acid spectrum accurate to subgroup B. amyloliquefaciens. The genome of this strain demonstrates the presence of five biosynthetic clusters most typical for this species, which are responsible for the biosynthesis of antimicrobial compounds such as fengycin, surfactin, bacillin, bacillisin, and siderophorous compound bacillibactin. The presence of such clusters is common to the most $B$. velezensis strains. It seems like present determinants of biosynthesis of macrolactin and difficidin are slightly less distributed (they are absent in 1 strain from 105 according to the study [27]). From five known for this species bacteriocins - subtilin, mersacidin, planthazolicin, LCI, and amylocyclicin - only the last two were found, and they are known generally for species $B$. amyloliquefaciens and different species of $B$. subtilis group, respectively [27]. Bacteriocin LCI even is a part of $B$. velezensis core genome [28].
The obtained data, in general, is supported by literature data on the specificity of $B$. velezensis genomes [29]. Revealed biosynthetic clusters prove the representation of this species as the most biosynthetically active among all other representatives of the $B$. amloliquefaciens subgroup [3]. It is known, that in some strains of this species secondary metabolites genes comprise about $8 \%$ of the genome, which is twice more than for B. subtilis [29]. Bacteria of this species are frequently associated with plants, and according to their ecophysiology are classified as plant growthpromoting rhizobacteria (PGPR). Among factors of such a biological activity are antimicrobial compounds, which are synthesized by bacteria of given species and frequently have antagonistic activity against bacterial and fungal pathogens [4].

Unidentified, but found by antiSMASH, genetic clusters require further investigations using methods of bioinformatics, molecular biology and biochemistry because they can be responsible for the synthesis of previously unknown biologically active compounds.

Strain B. velezensis ONU 553 is deposited in the Collection of the sea and useful microorganisms of Odessa I.I. Mechnikov National University and the sequenced genome is deposited in the GenBank database under accession number CP043416.

\section{ХАРАКТЕРИСТИКА ГЕНОМУ UTAMУ BACILLUS VELEZENSIS ONU 553, IЗОЛЬОВАНОГО 3 ДОННИХ ВІДКЛАДЕНЬ ЧОРНОГО МОРЯ}

\section{М.Д. Штеніков ${ }^{1}$, А.М. Остапчук', Н.Ю. Васильева ${ }^{1}$, А.М. Лужецький ${ }^{2}$} К. Рюкерт ${ }^{2}$ Й. Каліновські ${ }^{2}$ В.О. Іваниця ${ }^{1}$

${ }^{1}$ Одеський начіональний університет імені I.I. Мечникова, вул. Дворянська, 2, Одеса, 65000, Україна

${ }^{2}$ Інститут фармацевтичних досліджень Гельмгольияа землі Саар, Кампус E8 1, Саарбрюккен, 66123, Німеччина

Резюме

Пошук продуцентів біологічно активних метаболітів зміщується в напрямку дослідження штамів з екзотичних біотопів. Аеробні спороутворюючі бактерії з донних відкладень Чорного моря $\epsilon$ добрим прикладом таких мікроорганізмів завдяки легкості селективного виділення, підтримання в культурі та високій біосинтетичній активності. 
Мета. Проаналізувати структуру генома антагоністично активного штаму Bacillus sp. ONU 553, ізольованого з донних осадів Чорного моря, для його реідентифікації та виявлення генів, що відповідають за синтез біологічно активних сполук. Методи. Отриману геномну ДНК було секвеновано $з$ використанням секвенатору HiSeq 1500 (Illumina). Збірку геному здійснено з використанням асемблеру Newbler версії 2.8, визначення видової належності штаму - за допомогою сервера TYGS, підрахунок ANI - з використанням Ezbiocloud. Анотування геному здійснено за допомогою серверів PATRIC та NCBI PGAP, пошук кластерів біосинтезу антибіотиків та бактеріоцинів - за допомогою antiSMASH та Bagel4 відповідно. Пошук детермінант патогенності виконувався за допомогою IslandViewer, резистентності до антибіотиків - ResFinder-3.2, пошук профагових еле-

1. Schinke C, Martins T, Queiroz SCN, Melo IS, Reyes FGR. Antibacterial Compounds from Marine Bacteria, 2010-2015. J Nat Prod. 2017; 80(4):1215-1228.

2. Logan NA, De Vos P. Bacillus. In: Bergey's Manual of Systematics of Archaea and Bacteria. Whitman WB. John Wiley \& Sons, editors. Inc, 2015:1-164.

3. Fan B, Blom J, Klenk H.-P, Borriss R. Bacillus amyloliquefaciens, Bacillus velezensis, and Bacillus siamensis Form an "Operational Group B. amyloliquefaciens" within the B. subtilis Species Complex. Front Microbiol. 2017; (8):1-15.

4. Fan B, Wang C, Song X, Ding X, Wu L, $\mathrm{Wu} \mathrm{H}$, et al. Bacillus velezensis FZB42 in 2018: The Gram-Positive Model Strain for Plant Growth Promotion and Biocontrol. Front Microbiol. 2018; 162(9):1-7.

5. Ma Z, Hu J. Complete genome sequence of a marine-sediment-derived bacterial strain Bacillus velezensis SH-B74, a cyclic lipopeptides producer and a biopesticide. Biotech. 2019; 162(9):1-7.

6. Zhao P, Xue Y, Gao W, Li J, Zu X, Fu D, et al. Bacillaceae-derived peptide antibiotics since 2000. Peptides. 2018; 101:10-16. ментів - з використанням PHASTER. Результати. Встановлено, що розмір дослідженого геному сягає 3934563 пар основ, вміст ГЦ-пар складає 46,69\%. Виявлено 3953 відкриті рамки зчитування, $з$ них ідентифіковано 3252 (82 \%). Виявлено детермінанти шести антибіотиків і двох бактеріоцинів, а також чотири профаг-подібних елементи. Висновки. Проведені дослідження та порівняльний аналіз геному штаму Bacillus sp. ONU 553, ізольованого $з$ донних осадів Чорного моря, дають підстави підтвердити його ідентифікацію до виду Bacillus velezensis та роблять перспективним його подальше дослідження як потенційного пробіотика та джерела нових біологічно активних метаболітів.

Ключові слова: Bacillus velezensis, анотація геному, морські бактерії, донні відкладення, Чорне море, бактеріоцини, антимікробні сполуки.

7. Saggese A, Culurciello R, Casillo A, Corsaro MM, Ricca E, Baccigalupi L. A Marine Isolate of Bacillus pumilus Secretes a Pumilacidin Active against Staphylococcus aureus. Mar Drugs. 2018; 16(6);1-13.

8. Zhang DJ, Liu RF, Li YG, Tao LM, Tian L. Two new antifungal cyclic lipopeptides from Bacillus marinus B-9987.Chem Pharm Bull. 2010; 58(12):1630-34.

9. Shtenikov MD, Ostapchuk AM, Ivanytsia VO. Antagonistic activity of endosporeforming bacteria of deep water the Black Sea sediments. Microbiology \& Biotechnology. 2018; 43(3):82-89.

10. Ivanytsia VO, Shtenikov MD, Ostapchuk AM. [Facultatively anaerobic sporeforming bacteria of deep-sea sediments of the Black Sea]. Microbiology \& Biotechnology. 2017; 40(4): 94-103. Ukrainian.

11. Zhao X, Kuipers OP. Identification and classification of known and putative antimicrobial compounds produced by a wide variety of Bacillales species. BMC Genomics. 2016; 17(1):1-18.

12. De S, Kaur G, Roy A, Dogra G, Kaushik R, Yadav P, et al. A Simple Method for the Efficient Isolation of Genomic DNA from Lactobacilli Isolated from Traditional Indian Fermented Milk (dahi). Indian J Microbiol. 2010; 50(4):412-418. 
13. Meier-Kolthoff JP, Göker M. TYGS is an automated high-throughput platform for state-ofthe-art genome-based taxonomy. Nat Commun. 2019; 10(1):1 -10.

14. Yoon SH, Ha SM, Lim JM, Kwon SJ, Chun, J. A large-scale evaluation of algorithms to calculate average nucleotide identity. Antonie van Leeuwenhoek. 2017; 110(10):1281-1286.

15. Wattam AR, Brettin T, Davis JJ, Gerdes S, Kenyon R, Machi D, et al. Assembly, Annotation, and Comparative Genomics in PATRIC, the All Bacterial Bioinformatics Resource Center. In: Comparative Genomics. Methods Mol Biol. New York: Humana Press; 2018. p. 79-101.

16. Tatusova T, DiCuccio M, Badretdin A, Chetvernin V, Nawrocki EP, Zaslavsky L, et al. NCBI prokaryotic genome annotation pipeline. Nucleic Acids Res. 2016; 44(14):6614-6624.

17. Overbeek R, Olson R, Pusch GD, Olsen GJ, Davis JJ, Disz T, et al. The SEED and the Rapid Annotation of microbial genomes using Subsystems Technology (RAST). Nucleic acids research. 2014; 42(1):206-214.

18. Kalkatawi M, Alam I, Bajic VB. BEACON: automated tool for Bacterial Genome Annotation Comparison. BMC Genomics. 2015; 16(1):1-8.

19. Blin K, Shaw S, Steinke K, Villebro R, Ziemert N, Lee SY, et al. antiSMASH 5.0: updates to the secondary metabolite genome mining pipeline. Nucleic Acids Res. 2019; 47(1):81-87.

20. van Heel AJ, de Jong A, Song C, Viel JH, Kok J, Kuipers OP. BAGEL4: a user-friendly web server to thoroughly mine RiPPs and bacteriocins. Nucleic Acids Res. 2018; 46(1):278-281.

21. Bertelli C, Laird MR, Williams KR, Lau BY, Hoad G, et al. IslandViewer 4: Expanded prediction of genomic islands for larger-scale datasets. Nucleic Acids Research. 2017; 45:30-35.
22. Joensen KG, Scheutz F, Lund O, Hasman H, Kaas RS, Nielsen EM, et al. Real-time whole-genome sequencing for routine typing, surveillance, and outbreak detection of verotoxigenic Escherichia coli. J Clin Micobiol. 2014; 52(5):1501-1510.

23. Zankari E, Hasman H, Cosentino S, Vestergaard M, Rasmussen S, Lund O, et al. Identification of acquired antimicrobial resistance genes. J Antimicrob Chemother. 2012; 67(11):2640-2644.

24. Arndt D, Grant JR, Marcu A, Sajed T, Pon A, Liang Y, Wishart DS, et al. PHASTER: a better, faster version of the PHAST phage search tool Nucleic Acids Res. 2016; 44(1):16-21.

25. Liu J-Y, Pan N-S, Chen Z-L. Characterization of an anti-rice bacterial blight polypeptide LCI. Rice Genetics Newsletter. 1990; 7:151-154.

26. Scholz R, Vater J, Budiharjo A, Wang Z, He Y, Dietel K, et al. Amylocyclicin, a Novel Circular Bacteriocin Produced by Bacillus amyloliquefaciens FZB42. J Bacteriol. 2014; 196(10):1842-1852.

27. Silva FJ, Ferreira LC, Campos VP, CruzMagalhães V, Barros AF, Andrade JP, et al. Complete Genome Sequence of the Biocontrol Agent Bacillus velezensis UFLA258 and its Comparison with Related Species: Diversity within the Commons. Genome Biol Evol. 2019; 11(10):2818-2823.

28. Chun BH, Kim KH, Jeong SE, Jeon CO. Genomic and metabolic features of the Bacillus amyloliquefaciens group - B. amyloliquefaciens, $B$. velezensis, and B. siamensis - revealed by pan-genome analysis. Food Microbiol. 2019; 77:146-157.

29. Lin C, Tsai CH, Chen PY, Wu CY, Chang YL, Yang YL, et al. Biological control of potato common scab by Bacillus amyloliquefaciens $\mathrm{Ba} 01$ PLoS One. 2018; 13(4):1-17.

Received 27.09.2019 